\title{
Monuments as Spaces for Enhancing Social Justice and Sustainable Learning in History Teaching: A Case of the Voortrekker Monument
}

\author{
Boitumelo Moreeng \\ Faculty of Education, School of Social Sciences and Language Education, \\ University of the Free State, Bloemfontein, South Africa \\ Chitja Twala \\ Faculty of Humanities, Department of History, \\ University of the Free State, Bloemfontein, South Africa \\ E-mail: moreengbb@ufs.ac.za
}

\section{Doi:10.5901/mjss.2014.v5n7p491}

\section{Abstract}

The study proceeds from the premise that meaningful history teaching requires that educators should be able to expose their learners to different types of historical sources and resources in order enhance their quality of teaching. One of the ways of doing this is the use of monuments as spaces to supplement and support what is done in the classroom. Since monuments are made by people who had a particular perspective about the past, it is very important for educators to use monuments to encourage an open, engaging and critical way of looking at the past. The focus in this study is on how the Voortrekker monument can be used as an educational resource to enhance social justice and sustainable learning in history teaching. This will provide some answers to the debate on how history teaching can be enhanced through the use of monuments. For the purpose of this study, a critical pedagogical lens will be used to analyse the purpose and the displays at the Voortrekker monument. The study highlights how certain societal stereotypes; discursive sources of power; dominance; inequality and bias are still promoted by what is depicted at this monument. Furthermore, the study argues for the use of critical pedagogy in explaining the Voortrekker monument as space for history teaching and learning. Lastly, the study demonstrates the need to reorganise such monuments in a more inclusive manner to enhance social justice and sustainable learning in history teaching.

Keywords: Monuments, Pedagogy, Sustainable Learning, Teaching, Historians, Education

\section{Introduction}

In the past, the teaching of history in South Africa seemed to be aided and abetted by the popular notion that 'history' was a body of information recorded about the past without contextualising it in the present. While South African historians have extended the field and the range of historical inquiry about the teaching of the country's history, little has been achieved in documenting the relevance of monuments in the teaching of the discipline. To date there is a dearth of research and literature on the critical historical value of monuments and the role they can play in enhancing social justice and the sustainable learning of history. The discussion in this study seeks to fill this hiatus. Using the Voortrekker monument as a case in point, the study shows how the displays inside this monument can send different messages to learners of history if the monument is used as space for history teaching.

\section{Aims and Objectives of the study}

The primary aim of this study is to investigate the extent to which and how best monuments, in post-apartheid South Africa, can be utilised to enhance the course of social justice and sustainable learning in history teaching. In the teaching of history, particularly in post-apartheid South Africa, learners are exposed to different monuments which in one way or another can trigger divergent viewpoints from both learners and educators. Using the Voortrekker monument in Pretoria as a case in point, the study exposes the different viewpoints that such a monument can advance in the teaching of history. The study is based on research that is described as both exploratory and applied. 


\section{Literature Review}

Moreeng and Du Toit (2013: p45) argue that in recent years, the school subject History has been subjected to continuous scrutiny aimed at establishing itself as a dynamic subject with regard to knowledge construction and skills development. After 1994, South Africa adopted a new approach to the teaching and learning of history. Factors that led to a change in the way history is taught in South Africa received attention in several academic papers that focused mainly on teaching methodology and assessment. Some papers concentrated mainly on historicising and categorising monuments to highlight the divergent viewpoints they portray. Such papers project the divisive nature of such monuments from a historical point of view (Twala and Selesho, 2013: p247-253; Hlalele, 2014: p101-110). Few, if any, have explored the use of monuments in teaching history in South Africa for enhancing social justice. This study attempts to contribute to the above notion of using monuments as spaces for enhancing social justice and sustainable learning.

\section{Theoretical Framework}

Academic studies on monuments are both relevant and timely as they come at a time in which South Africa as a nation can be described as defining and re-defining itself against the backdrop of apartheid. However, there is a need to appropriate such monuments in enhancing social justice as meaningful tools in the teaching of history. This will make all monuments, 'old' and 'new' in order to remain relevant and vital to society.

\section{Research Methodology}

The study provides new insight into the use of monuments for the purpose of enhancing social justice in the teaching and learning of history. More importantly, it uses literature addressing issues of critical pedagogy (CP). A narrative approach is pursued. For the purpose of this study, the information was collected by accessing literature on the topic under discussion which incorporates chapters in books, books, journal articles and dissertations. The study follows a qualitative approach by including an interpretation of relevant sources for the purpose of discovering and understanding meaning and the pattern underlying the teaching and learning of history in post-apartheid South Africa.

\section{Discussion and Findings}

\subsection{Monuments}

\subsubsection{Monuments as contested spaces}

Monuments are viewed as constructs that seek to embody and celebrate the founders of the nation and heroes of a particular group or nation, thereby offering an individual in society an image of their membership of that society. According to Seixas and Clark (2004: p155) monuments are mainly used to celebrate the works of extraordinary people, whose characters should be emulated at - least in the eyes of the monument builders. When they do not celebrate individuals they mark victories and other key events from a nation's past. They are educational institutions and have a unique ability to reach not only learners of history, but also adults and international visitors. Furthermore, Seixas and Clark (2004: p147) view the monuments as pedagogical sites whose messages are intended to convey value to successive generations. Thus, Foxall (2013: p198) views monuments as embodiments of official history and memory, intended to convey values to the next generation. In the process, a monument may inspire debate and evolve meaning that is influenced by the person looking at it at a given time. Monuments thus become places where national traditions are invented, and forms of political power become facilitated by meanings that are not fixed (Crampton, 2001: p223).

\subsubsection{The pedagogical value of monuments in the teaching of history}

Not all monument displays are appreciated and accepted by all members of the society; some convey issues that are no longer seen as worthy of celebrating (Seixas and Clark, 2004: 147). Some of the monuments are displays of events or individuals that nations would like to forget and move on with their lives or continue to build their nations. Unfortunately, this is not an easy process as reflected by Bhabha (1994: p160-161) when he refers to how forgetting constitutes the beginning of a nation's narrative; how being obliged to forget becomes the basis for remembering the nation, peopling it anew and imagining the possibility of other contending and liberating forms of cultural identification. 
One other value of monuments is that they have the potential to promote the issue of memorialisation. According to Foxall (2013: p167) memorialisation is projected as a complex process that forces those who engage with it to form their own interpretation, thereby producing, reproducing and challenging a national narrative which is open to critical readings and interventions by citizens. By so doing, the dominant networks and relations of power in both society and a nationstate project are undermined. Dealing with political memory is even more problematic as politics is never uncontested; rather, it is actively constructed, maintained or challenged at the everyday level. In some instances, sometimes old-era figures are resurrected through monuments.

Larsen (2012: p45) avers that public monuments during colonial times were used to assert imperial power and entrench settler identity through what Bourdieu (1990: p108) refers to as a process of officialisation. During the process of officialisation, the dominant group teaches itself and masks from itself its own truth, binds itself by a public profession which sanctions and imposes what it utters and contributes to the maintenance of the social order from which it derives its power. Thereby, it regulates interpersonal relationships and social status.

It is argued in this study that the process of monumentation is a primary method by which nations and peoples revisit their cultural identities. It is not about the past but about the meanings attached to the present and the future. Learners are afforded an opportunity to reflect on people or events, not to blindly accept what they see. This process encourages thoughtful and informed criticism and engages in a form of dialogue regarding the legacy of the memorilised person or event.

\subsubsection{Dealing with monuments as places of memory}

Dealing with monuments and other places of memory after critical junctures in history is a very sensitive issue especially in complex societies which are diverse in terms of culture, religion, language, ethnicity and race. They result in what Foxall (2013: p168) refers to as the politics of memory. These memories are never uncontested; instead they are actively constructed, maintained or challenged at the everyday level. It becomes even tougher in countries which are seeking to assert themselves as nation states, such as South Africa, Rwanda, Northern Ireland, Sudan, India, Kenya, Germany and post-USSR Russia. They have co-opted/glorified, disavowed, or contested their monuments. Co-opted/glorified monuments are maintained or exulted further. Disavowed sites are literally or symbolically erased from the landscape, either through active destruction or neglect by the state. Contested monuments remain the objects of political conflict, neither clearly glorified nor disavowed. The Voortrekker monument in South Africa serves as an example of such contested monuments. It is a site that has so much meaning for a section of the community (white Afrikaners), but is nevertheless treated as a national monument or as part of South Africa's heritage (Suttner, 2006: p4).

The complex nature of meanings established from the Voortrekker monument presents it as a powerful pedagogical site that gives educators and learners an opportunity to inform memory making through highlighting actors and interrogating the specific sources involved and excluded. In the process, a particular narrative is constructed and the historical memory-making that is meaningfully and educational becomes fun. With this in mind, it is not only important to look into the general role that monuments play in society and how they portray the country's turbulent past, but also specifically how they can enhance social justice and sustainable learning in history teaching.

The debates around the monument either popular, scholarly or the views held locally will compel the learners to read, investigate, discuss and debate about the monument. Monuments should therefore assist in enhancing historical consciousness which involves passing down practices and tools for understanding the past. Monuments can also assist in the promotion of social cohesion and conscientising visitors around the issues of power, dominance, inequality, bias, subjectivity and stereotyping.

\subsection{A brief historical background on the Voortrekker monument}

To understand the relevance and significance of the Voortrekker monument and the role it played in the past in establishing the cultural identity of the Afrikaner, it is necessary to look briefly at why it was erected, as well as at the socio-economic and political climate in which it was erected. During the Great Trek, the Voortrekkers migrated from the Cape Colony to the interior of the country between 1835 and 1854. The activity prompted calls for self-rule and Afrikaner pride, especially as the conservative Afrikaner Broederbond was able to portray the centenary as an ethnic revival of the language, dress and spirit of the original Voortrekkers, escaping what was viewed as the British tyranny (Meents, 2009: p83). The monument was inaugurated on 16 December 1949 to commemorate the Great Trek into the interior of South Africa and the Day of the Covenant, an Afrikaner holiday marking the occasion when fewer than 500 Voortrekkers, led by Andries Pretorius, defeated 10000 Zulu fighters in retaliation for a Zulu attack in the Battle of Blood River in 1838. 
Therefore, the holiday and the monument itself infuse religious beliefs with nationalist ideology as both symbolise the trekkers' vow to faithfully serve God in gratitude for their miraculous defeat of Chief Dingane of the Zulus (Autry, 2012: p149).

According to Autry (2012: p149), the construction of the Voortrekker monument helped consolidate a set of heroic narratives about a shared ethnic past; one that united all Afrikaners and legitimised political claims for power, architecturally influenced by grand designs in Paris and Leipzig. This fort-like structure was presented as a defiant move to define and assert itself as a symbol of Afrikanerdom (Steenkamp, 2006: p250). The monument served to promote Afrikaner nationalism, ethnic mythmaking and to promote the ideals of apartheid. In the monument, the Afrikaner are depicted as caught in an immutable form of historical consciousness trapped by racism, by religion, by the myths and by their history which contributed to the apartheid mindset (Grundlingh, 2001: p95-112).

A strong underlying message that seeks to permeate the story of the Voortrekker monument is that of a reminder of the courage, determination and persistence of the Voortrekkers. This message therefore projects Afrikaners as a chosen nation, as survivors and as victims of attacks from Africans (Leslie, 2000: p35). In addition, the Afrikaners are depicted as having a strong cultural capital which is viewed by Wink (2005: p39) as process of powerful practices, as ways of behaving, talking and moving amongst others that are determined by the dominant culture, thus promoting success for specific groups.

Furthermore, Autry (2012: p146) notes that this monument has stood as the embodiment of Afrikaner nationalism and mythology and has survived its possible demolition after 1994, due to the purported spirit of national reconciliation promoted by the African National Congress (ANC) as the ruling party in South Africa. Furthermore, Autry (2012: p146147) argues that most white South Africans during the colonial and apartheid periods, could easily identify with national cultural symbols that constructed them as insiders, while constructing the majority of the population as national outsiders. In the aftermath of apartheid, political leaders and heritage professionals grapple with the challenge of representing a national history marred by centuries of intense conflict. While this involves the creation of new national markers and styles of commemoration, it also entails serious engagement with the inherited apartheid material culture that fuelled Afrikaner nationalism. In order for the monument to remain relevant and secure state funding, attempts were made to align it to be more inclusive, rather than to be viewed as an Afrikaner icon. The authors in this study argue that this was done with limited success.

In the past, the Voortrekker monument served as the backdrop of a counter-commemoration organised by the Conservative Party (CP) and the far-rightwing Afrikaner Weerstandsbeweging (AWB). These parties not only rejected outright government reform to the system of apartheid, they also denounced the National Party (NP) itself as a traitor to Afrikanerdom. Rasool, Mitza and Minkley (2000: p121) contend that they expected that one of the instant imaginings accompanying the end of apartheid would be the destruction of the many symbols and memorials of apartheid. However, almost 20 years in democracy, nothing has happened to the Voortrekker monument, probably because of the policy of nation building and reconciliation pursued by the ANC and an acknowledgement that the monuments are significant for personal connections and for promoting historical consciousness. During the post-1994 period there has instead been a strong top-down support for the construction of new monuments and memorials, aimed at promoting the new national ideas of unity and reconciliation, representing those that were previously silenced and marginalised under the old regime and to reflect broader society's history and the struggle for freedom and values (Labuschagne, 2010: p112). Burns (2006: p2) notes that the subjective, creative and constructed nature of cultural memory has allowed South Africa to use its problematic and contested past to reconstruct its identity symbolically, and in the process attempt to manage social conflict and create unity.

It is in line with the above argument that the study on the Voortrekker monument is undertaken to propose different ways in which it could be used to enhance nation building and national unity. Thus, the issue of monuments is not simply an academic question. The study argues that the Voortrekker monument should be able to remain receptive to its viewers as opposed to reducing them to passive spectators. Therefore, in order to achieve this depends on how history teachers and learners deal with the displays inside and outside this monument and the explanations provided about the monument.

\subsection{Implication for history/heritage teaching and learning}

As previously indicated, the aim of the study is to discuss the implication and impact of the displays at the Voortrekker monument on the teaching and learning of history. Hypothesising on the possible pedagogical approaches to dealing with monuments during history lessons, the pronouncements from the constitution and the requirements of the Curriculum and Assessment Policy Statement (CAPS) document seem to call for a kind of pedagogy that will encourage active and 
critical engagement with content/knowledge (DoBE, 2011; RSA, 1996). The documents also seem to advance an environment of flexibility to unlearn and learn new meanings and not to accept things at face value. In order to make a contribution to the body of knowledge involving the use of monuments in teaching history, the authors in this study sought support from the wisdom provided by the critical pedagogy, as it seems to be the most appropriate framework with which to address these needs.

\subsubsection{Critical pedagogy $(C P)$}

Critical Pedagogy (CP) is part of the transformative pedagogies and it is associated with Giroux and fundamentally linked to and buttressed by the Frankfurt School's Critical Theory (Davis and Harrison, 2013: p86; Wink, 2005: p29). The foundations of CP might be seen in how Freire warns that educators should not impose their ideas on learners; instead educators should respect the students' cultural identity and believe in the total autonomy, freedom and development of those he or she mentors. The task of the educator is therefore a liberatory one (Freire, 1997: p324). The call for liberation by Freire seems to be echoed by Giroux in his appeal to educators to become 'transformative intellectuals'. Furthermore, the influence of the Gramscian concept of hegemony and Foucault's pronouncement about power and power relations are also acknowledged in defining and conceptualising critical pedagogy (Davis and Harrison, 2013: p86).

Wink (2005: p1) believes that the definition of CP is a complex and evolving one. Without attempting to strictly define the concept critical pedagogy, we support Wink's (2005: p1) attempt to simplify it. Her approach is to look at the meaning of the two words: in this case, Critical is seen as a process that incorporates seeing deeply what lies below the surface and involves thinking, critiquing and analysing what one encounters. In addition, Luke (2012: p5) views the practice of being critical as the ability to argue and to judge. On the other hand, Pedagogy is understood not only as implying how to teach, but also about the visible and hidden interactions between the teacher and learner, whether in the classroom or in the wider community (Wink, 2005: p1).

Other scholars maintain that $\mathrm{CP}$ is a cognitive and rational activity of inquiry, analysis and discourse action which holds the assumption that society can be changed through critical action dialogue and education, are also noted. CP further assumes that people want to learn and to use language and its analytical structures to challenge existing structural power dynamics. In CP, praxis is viewed as an educational tool for eliminating oppressive relationships and strives for conditions which are emancipatory, liberatory and revolutionary. CP focuses on the relationship between knowledge, power and the democratisation of pedagogy, thereby steadfastly dismissing the mainstream assumption of knowledge as objective, neutral and given. Cho (2007: p318) purports that CP is against structural determinism as it focuses on the lived experiences of individuals by representing their self-realisations and self-expressions. Thus, it is seen as a major player in the transformation of knowledge and pedagogy.

An analysis of the concept of CP provided in the preceding paragraphs helps us to make meaning of how history teaching can be enhanced through the use of monuments, which is a process, as this paper demonstrates, that should stimulate critical engagements with the displays and interpretations posed by these spaces, thereby realising the principle of reading and unpacking the world as postulated by Luke (2012: p5). CP therefore becomes a relevant framework and a lens through which we engage with the use of monuments as spaces for enhancing social justice and sustainable learning in history teaching and learning.

The focus in the following section will be to locate the teaching and learning of history using the Voortrekker monument within a CP framework by focusing on hegemony and conscientisation as concepts that are fore-grounded by $\mathrm{CP}$. We focus on these two concepts to illustrate how they can influence and impact on how the Voortrekker monument can be dealt with.

\subsubsection{Hegemony and power}

One of the most dominating themes that seem to permeate the Voortrekker monument is that of Afrikaner hegemony and power. This is reflected in the design and the explanation given in the official documents of the reasons behind the creation of the monument and the reasons provided in the literature. Autry (2012: p149) alludes to this when proclaiming that the construction of the Voortrekker monument helped to consolidate a set of heroic narratives about a shared ethnic past; one that united all Afrikaners and legitimised political claims for power. For Seixas and Clark (2004: p154-155) this is a further attempt to establish continuity and identity with the past by invoking a debt of remembrance to fore bearers, victims of injustice, protectors and leaders who contributed or sacrificed themselves, thus instilling the Afrikaner hegemonic sense. Larsen (2012: p45) does not view this as being important by asserting that monuments have been 
used to assert imperial power and entrench settler identity. The Voortrekker monument is discriminatory in nature as it was conceived to represent the cultural and bodily struggle for territory for the Afrikaners (Steenkamp, 2006: p250).

Hegemony as a concept talks to the political decisions, economic interests and pedagogical domination of one group over another with the partial consent of the dominated group (Davis and Harrison, 2013: p84). This is reflected in Grundlingh's (2001) assertion that the reason for the creation of the monument was to promote Afrikaner nationalism, ethnic mythmaking and to promote the ideals of apartheid. Thus, in the Voortrekker monument no other group is projected in the same light as the Afrikaners. The purpose is therefore that of reinforcing the status quo thereby protecting the privileged and normalising the process in which a particular way of comprehending social reality is fabricated or forged through ideas, language, perspectives, theories and other forms of discourse. Consequently, these become so embedded that they are accepted as common sense or as part of the natural order. As a result, monuments, such as the Voortrekker monument became powerful spaces because they informed the habitus - a web of practices, understandings and structures aimed at defining and sustaining what constitutes particular societies, thus becoming part of symbolic capital (Bourdieu 1990: p108).

The main concern of $\mathrm{CP}$ is to call us to action by encouraging people to unlearn, unpack and rewrite their experiences and assumptions (Wink, 2005: p9). Knowledge emerges through invention and reinvention; through the restless, impatient, continuing, hopeful inquiry human beings pursue in the world, with the world and with one another. It further recognises that history and political-economic conditions shape how meaning is made by providing boundaries to what seems possible and thus orienting one toward sanctioned norms, values and what is considered appropriate behaviour embedded in curriculum and teaching practices. It is clear from the above that $\mathrm{CP}$ should be used for the purpose of counter-acting the spread of hegemony and power which could be detrimental to the teaching and learning of history in South Africa.

Monuments as historical creations also fall into this picture as they are informed by how people interpret their past and how they want it to be understood. CP questions and problematises these creations by exposing and questioning how the processes by which certain information is validated or invalidated. It acknowledges that knowledge is socially constructed, historically produced, economically influenced, mediated through hegemony and reinforced through power. Recognising and dealing with this acknowledgement will go a long way to developing and enhancing an affective social justice practice that leads to self authorship and the liberation of members of society. It is a teaching approach which attempts to help students question and challenge domination, and the beliefs and practices that dominate them, thereby disrupting the power imbalances that are present in education settings especially as affected by issues of class (Davis and Harrison, 2013: p85).

The issue is not the monument but the message that it seeks to project and what underlying messages of power are embedded in the monument. The focus of $\mathrm{CP}$ is on knowledge and power; thus, ideology critique and discourse analysis are employed as powerful conceptual tools to elucidate the interconnectedness between knowledge and power (Cho, 2010: p310). Therefore, CP questions not only the knowledge, but also the method used in projecting the knowledge, thereby exposing hegemonic practices.

\subsubsection{Conscientisation}

The second concept that seems to be dominant in CP is conscientisation. The process of conscientisation moves away from passivity as it is a process through which students as empowerment subjects, acquire a deepening awareness of the contextual realities that shape their lives and begin to discover their own capacities to create them (Wink, 2005: p33). It tries to make students critically conscious, which according to Shor (1992) is the ability to think, read, write and speak while going beneath the surface meaning; going beyond the myths, clichés, received wisdom and mere opinions. When the pedagogic environment encourages critical consciousness it allows for the ability to engage in deep meaning, root causes and the social context. Critical consciousness also seeks to expose the forces that prevent individuals and groups from making decisions that will affect their lives; it enables learners to question knowledge that is presented as objective, neutral and given. Most importantly, it gives learners a choice through which, as Cutts (2012: p146) maintains, it is only through our choices as a people and our refusal to be oppressed that consciousness of victory might be attained. Moreover, it frees students from oppressive cultural frames and provides them with new ways of claiming authority for their own experiences.

Consciousness leads to naming, and aims to construct alternative or counter-hegemonic forms of knowledge through exposing and identifying those social processes that promote hegemony and social injustice. When people are conscious, they have the potential to reorient the discourse by creating spaces for transgression against socially unjust practices, thereby developing a critical stance towards context and content (Nkoane and Lavia, 2012: p60). In such a 
space learners and teachers are actors in history as they interrogate knowledge that is transmitted from generation to generation, constantly recreating it for the benefit of communities and groups. People are therefore consciously trying to create a sense of identity and continuity in the form of an educational practice of progressive option which is essentially an adventure in unveiling (Freire, 2008: p1).

Using the Voortrekker monument as a case study in an attempt to promote social justice in the teaching and learning of history, it is important for the learners to become aware of the divisive nature of the monument with the displays glorifying the history of only the Afrikaners. For the purposes of nation building and social cohesion, such monuments need to be embracive and show the nature of South African citizenry. In order to achieve the above, CP is necessary when approaching such monuments. In defence of the above, Kros (2010: p63-76) argues that the story of the Voortrekkers as depicted in this monument is a reminder to the public of the courage, determination and persistence of the Voortrekkers, but not of their brutality and determination to exclude all non-whites from the definition of citizenship in their nascent republics.

\section{Concluding Remarks}

The paper is not arguing for the removal of such monuments but seeks to encourage multiple ways of interpreting the messages that are projected. A preferred one is the language that will build and nurture a more socially just and sustainable learning environment. The need is for spaces that are not proscriptive of any truth but offer a mnemonic space that activates memory and accommodates diverse and complex meanings. For memorials, such as the Voortrekker monument, change is needed because apartheid and colonialism were deliberate and negative acts; therefore, nation building requires a concerted effort which should be unapologetic. In this study the authors argued the importance of using the monuments in the teaching of history with an aim of enhancing social justice.

\section{References}

Autry RK 2012. 'The monumental reconstruction of memory in South Africa: The Voortrekker Monument'. In Theory, Culture and Society, 29: 146-147. Bhabha $\mathrm{H}$ 1994. The location of culture. London.

Bourdieu P 1990. The Logic of Practice. Stanford: Stanford University Press.

Burns M 2006. 'A Completion of Memory? Commemorating a decade of freedom in South Africa: 1994-2004'. In Eras, 8 November: 2.

Cho S 2007. 'Politics of Critical Pedagogy and New Social Movements'. In Education Philosophy and Theory, 42(3): 310-325.

Crampton A 2001. 'The Voortrekker Monument, the birth of Apartheid and beyond'. In Political Geography, 20: 221-246.

Cutts QM 2012. 'A critical pedagogy of place'. In Journal of Curriculum Theorising, 28(3): 142-150.

Davis T and Harrison LM 2013. Advancing Social Justice. Tools, Pedagogies and strategies to Transform your campus. San Francisco: Jossey Bass.

Foxall A 2013. 'A contested landscape: Monuments, public memory and post-Soviet identity in Stavropol, Russia'. In Communist and Post-Communist Studies, 46 : 167-178.

Freire P and Fraser JW (eds) 1997. Mentoring the Mentor: Critical Dialogue with Paolo Freire. New York: Peter Lang.

Grundlingh A 2001. 'A Cultural Conundrum? Old Monuments and new regimes: The Voortrekker monument as a symbol of Afrikaner power in a post-apartheid South Africa'. In Radical History Review 81: 95-112.

Hlalele D 2014. 'Creating Sustainable Rural Learning Ecologies in South Africa: Realities, Lessons and Prospects'. In Journal for Human Ecology, 45(2): $101-110$. Kros C 2010. 'Public History/Heritage: Translation, Transgression or more of the same?' In African Studies, 69(1): 63-76.

Labuschagne P 2010. 'Monument(al) meaning making in the 'new' South Africa: Freedom Park as a symbol of a new identity and freedom?', SAJAH, $25(2): 112$. Larsen L 2012. 'Replacing imperial landscapes: colonial monuments and the transition to independence in Kenya'. In Journal of Historical Geography, 38: $45-56$. Leslie M 2000. 'Bitter monuments: Afrikaners and the new South Africa'. In The Black Scholar, 34(3): 33-39.

Luke A 2012. 'Critical Literacy: Foundational Notes'. In Theory into Practice, 51: 4-11.

Meents TL 2009. 'Deconstructing Museums and Memorials in Pre- and Post-Apartheid South Africa', Unpublished MA Thesis. University of South Africa, Pretoria. November: 83.

Moreeng BB and Du Toit E 2013. 'The powerful learning environment and history learners in the Free State'. In Yesterday and Today, 9, July: 45-46.

Nkoane MM and Lavia J 2012. Rethinking Education in South Africa: Amplifying Liberation Education. In Lavia J and Mahlomaholo S (eds), Culture, Education and Community. Expressions of the Postcolonial Imagination. Palgrave Macmillan. New York.

Rasool C, Witz L and Minkley G 2000. 'Burying and Memorialising the Body of Truth: The TRC and National Heritage'. In James W and Van de Vijver (eds), After the TRC: Reflections on Truth and Reconciliation in South Africa. Cape Town: David Philip Publishers (Pty) Ltd.

Seixas P and Clark P 2004. 'Murals as Monuments: Students' ideas about depictions of civilization in British Columbia'. In American Journal of Education, 110: 146-171.

Steenkamp A 2006. 'Apartheid to democracy: representation and politics in the Voortrekker Monument and Red location museum'. In Architectural Research Quarterly, 10: 249-254.

Suttner R 2006. 'Talking to the ancestors: National heritage, the Freedom Charter and nation-building in South Africa in 2005'. In Development Southern Africa, 23(1): 3-27.

Wink L 2005. Critical Pedagogy. Notes from the real world. Pearson Education: Inclu Boston.

Twala C and Selesho J 2013. 'Exploitation of Public Representations in the tuition of History in a post-apartheid South Africa: Ecosystem'. In Journal of Human Ecology, 44(3): 247-253. 